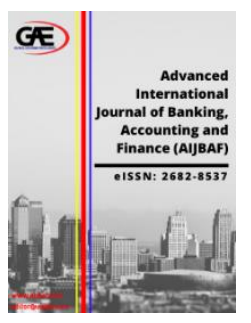

\author{
ADVANCED INTERNATIONAL JOURNAL OF \\ BANKING, ACCOUNTING AND FINANCE \\ (AIJBAF) \\ wWw.aijbaf.com
}

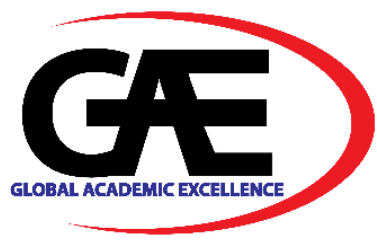

\title{
THE IMPACT OF MONETARY POLICY ON THE ECONOMIC GROWTH OF KUWAIT FOR THE PERIOD OF 1980-2020
}

\author{
Nor Asmat Ismail ${ }^{1 *}$ \\ 1 School of Social Sciences, Universiti Sains Malaysia, 11800 Minden, Penang, Malaysia \\ Email: norasmat@usm.my \\ * Corresponding Author
}

\section{Article Info:}

Article history:

Received date: 09.09.2021

Revised date: 04.10 .2021

Accepted date: 14.10 .2021

Published date: 01.12.2021

\section{To cite this document:}

Ismail, N. A. (2021). The Impact of Monetary Policy on The Economic Growth of Kuwait for The Period Of 1980-2020. Advanced International Journal of Banking, Accounting, and Finance, 3 (9), 01-14.

DOI: $10.35631 /$ AIJBAF.39001.

This work is licensed under $\mathrm{CC} B \mathrm{BY} 4.0$ (c)

\begin{abstract}
:
The government of Kuwait has shifted its focus from the dependence on oil and has concentrated on applying a long-term strategic vision that seeks to recover the economy and raise the citizens' standard of living. To accomplish these objectives, monetary policy should be formulated appropriately by the government. However, it seems that the effects of monetary policy instruments on the economic growth of Kuwait are not obvious. Therefore, the main purpose of this study is to empirically explore the effect of monetary policy on Kuwaiti economic growth. This research uses annual time series data on real GDP, exchange rate, broad money supply (M2), consumer price index, and deposit interest rate over the period (1980 - 2020) and applies Vector Error Correction Model (VECM). The results of the empirical analysis show the presence of a long-run relationship between real Gross Domestic Product and monetary policy instruments. Specifically, it finds that broad money supply (M2), deposit interest rate, and consumer price index affect economic growth positively and statistically significant. While the exchange rate affects real Gross Domestic Product negatively and statistically insignificant. The Granger causality test based on VECM shows two unidirectional causal relationships running from broad money supply and consumer price index to real GDP in the short run. Thus, the study suggests that policymakers concentrate on improving the economy by managing interest rates and maintain supporting environment for sustainable economic growth and development.
\end{abstract}

Keywords:

Monetary Policy, Economic Growth, VECM, Kuwait 
Volume 3 Issue 9 (December 2021) PP. 01-14 DOI 10.35631/AIJBAF.39001

\section{Introduction}

Kuwait is a small and oil-based economy that used an export approach as a basic technique to enhance the economy. Furthermore, Kuwait has encountered a wonderful growth rate and a massive increase in the GDP per capita throughout the previous decades. The monetary approach of the Central Bank of Kuwait is similar to other Gulf states and throughout the study period, it can be divided into three periods. First, tight monetary strategy over the period (19801986). Then, neutral monetary policy over the period (1987-1999). Lastly, over the period (2000-2020), easy monetary strategy comparing to the last two periods. The efficiency of monetary policy in Kuwait is constrained by the size and structure of the economy and the resulting problems. The most important obstacles that limit the function and the effectiveness of monetary policy are: first, government spending that dominates the economic activity in general. Secondly, oil revenues that dominate more than half of the national income. Finally, the weak structure of the domestic financial market. The state of Kuwait is mindful that the dependence on oil revenue is an exhaustible resource for achieving sustainable economic growth. Therefore, the government has shifted its focus from the dependence on oil and has concentrated on applying a long-term strategic vision that seeks to recover the economy and switching it into a financial and trade centre.

This study aims to investigate whether monetary policy affects Kuwaiti economic growth. The results of the study could help the policymakers to suggest the right policy to improve economic growth since the government shifted its focus from the reliance on oil revenue. The study regarding monetary policy and economic growth in Kuwait is very scanty. The latest study conducted by Nadeem et al. (2017), but they investigated the long-run role of oil income in the development of Kuwait as well as the direct effects of oil revenue, foreign output, and equity price shocks on real output. Hamza et al. (2020) explore the dynamic causal relationship between economic growth and financial development in Kuwait, covering the period between 1991 and 2017. They used the Toda-Yamamoto estimation technique and found that there is no causal direction was found. The second estimation was Fourier Toda-Yamamoto timedomain techniques and they found that the causality flowing from financial development to economic growth. Measurement for financial development was broad money supply as a proportion of GDP (M2), liquid liabilities as a proportion of GDP (M3), bank deposit as a proportion of GDP, and domestic credit provided to the private sector as a proportion of GDP.

This study differs from Hamza et al. (2020) because this study used a longer period (19802017) of data and using different variables (consumer price index, broad money supply, deposit interest rate, and exchange rate) to examines the effect of monetary policy on Kuwait economic growth. Furthermore, this study used different estimation techniques (Johansen Cointegration test, VECM, Granger Causality tests, and Impulse Response Function). The consumer price index was chosen as an independent variable to test whether the monetary policy in Kuwait can be explained by the Classical Monetary Theory. According to the Classical Monetary Theory, an increase in money supply will raise the price proportionally. According to the Keynesian transmission mechanism, an increase in money supply will decrease interest rate which in turn lowers the cost of funds available for lending and will encourage investors to invest more which results in increasing the output. Therefore, the interest rate variable and exchange rate variable were used in the model to test this theory. Therefore, this study Copyright (C) GLOBAL ACADEMIC EXCELLENCE (M) SDN BHD - All rights reserved 
Volume 3 Issue 9 (December 2021) PP. 01-14 DOI 10.35631/AIJBAF.39001 contributes to the literature on monetary policy and economic growth in Kuwait since the government shifts its focus from the reliance on oil revenue to monetary policy instruments.

\section{Theoretical Review}

\section{The Classical Monetary Theory}

Irving Fisher has laid the basis of the Classical Monetary Theory that assumed the velocity of money (V) and the output (Y) is constant. Given that both Y and V are fixed, an increase in the money supply would only eventually raise the prices proportionally. The equation of exchange as well implies that money supply is considered to affect aggregate output and price level positively given velocity constant. Thus, either prices or output will increase or both of them will increase as a result of increasing the money supply. On the other hand, if the economy is fully employed, the prices will increase faster than output. On the other hand, the output will increase more than prices, if there is a recession in the economy. It assumes that when an expansionary (or contractionary) monetary strategy is used by central banks, it will lead to rising (or dropping) in money supply (MS), which will cause increasing (or decreasing) in prices, according to Enock and Nicholas (2018).

$(\mathrm{M} . \mathrm{V})=(\mathrm{P} . \mathrm{Y})$

Where, $\mathrm{M}=$ money supply, $\mathrm{V}=$ velocity of money, $\mathrm{P}=$ price level, $\mathrm{Y}=$ output The equation of exchange has been transformed into the quantity theory of money where $\mathrm{V}$ becomes constant in the short run and money supply determines nominal income.

$\mathrm{M}=\mathrm{k}(\mathrm{P} . \mathrm{Y})$

To illustrate, Keynes rejected this equation with the (V) is unstable and not constant. Keynes has developed the liquidity preference concept into the liquidity preference theory which assumes that both interest rate and money supply affect output. Therefore, to enhance the economic output, the government must control monetary policy by managing the money supply and setting the interest rate in a way that adapts to the situation of the economy.

\section{Keynesian Transmission Mechanism IS-LM Model}

According to the Keynesian transmission mechanism, to enhance the output, the government can manage monetary policy by using many channels. The first channel is the interest rate, an increase in money supply will decrease interest rate which in turn lowers the cost of funds available for lending and that will encourage investors to invest more which results in increasing the output. While using expansionary monetary policy by increasing money supply would raise the expected price level which raises expected inflation which in turn decreases interest rate that would increase investment and output. Secondly, the exchange rate channel, which changes the relative prices of domestic and foreign goods by using expansionary monetary policy, decreasing the interest rate by increasing money supply would increase the exchange rate (domestic currency depreciates). While real depreciation in the exchange rate will make export cheap and, in this way, the country's exports and output would rise. Thirdly, bank lending channel, using expansionary monetary policy by increasing money supply, bank's deposits would increase which in turn increase the quantity of loans available to lend, lower 
Volume 3 Issue 9 (December 2021) PP. 01-14 DOI 10.35631/AIJBAF.39001

the interest rate and increase investment which leads to increase the outputs. Thus, the central banks use this indirect channel to influence output.

\section{The Monetarist Theory}

Increasing the standard of living and raising GDP per capita requires sustainable economic growth which can be achieved by appropriate monetary policies. The fundamental driver that influences the country's economy is the adjustments of money supply and this is what monetary theory assumes. Furthermore, the monetarist emphasized that money supply affects economic growth and accepted the necessity of an efficient monetary policy to achieve stabilization in the economy. However, they assume that the money supply must be growing at a fixed rate instead of being adjusted and managed by policymakers to achieve sustainable economic growth. According to Friedman (1982), central banks play an important role in affecting the economy through an open market operation. When the central bank buys (or sells) the securities from holders, the securities prices increase (or decreases), and the interest rate will fall (or increase), the securities holders will sell their securities and hold more cash. Consequently, they will be attracted by the low cost of funds and start borrowing from banks. While other people will spend their cash on buying financial assets and durable consumer goods. Therefore, using open market operation by central banks will raise investment and consumption, thereby raising national income. To illustrate, Keynes assumes that "money does not matter", his theory suggests that the relationship between money and output is very weak. Therefore, it assumes that money supply affects output indirectly via interest rate and investment. In a similar manner with a simple difference, Friedman assumes that "money matters", his theory assumes the existence of a direct relationship between money supply and output.

\section{Literature on Monetary Policy and Economic Growth}

There has been an extensive investigation on how real GDP is affected by money supply, inflation rate, interest rate, and exchange rate. Many empirical types of research have examined the link between monetary policy tools and economic growth in different countries (developed, developing) using different time series (annual, monthly, quarterly) and a different number of observations which have resulted in inconsistent outcomes. Srithilat and Sun (2017) have examined the monetary policy effects on the economic development of Laos. Their results suggest, in the long run, real GDP per capita is affected positively by the exchange rate. While it is affected negatively by other independent variables. The Granger Causality Test shows the presence of short-run relationships among the variables. Agbonlahor (2014) investigates empirically the effect of monetary policy on the U.K economic growth. He found, in the long run, there is a relationship between monetary variables and economic growth. The results also indicated that money supply and inflation rate are the most significant instruments that boost growth in the United Kingdom. Further research by Fasanya, et al. (2013) explored the effects of Nigeria's monetary policy on economic growth over the period (1975-2010). Their findings revealed the presence of a long-run relationship between independent variables and Nigeria's economic growth. In addition, it indicates that three of the variables (inflation rate, exchange rate, and external reserve) are the most powerful tools that boost the economy. 


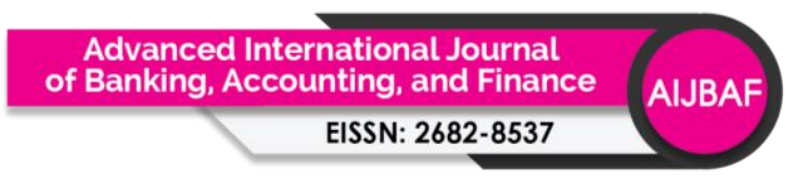

Volume 3 Issue 9 (December 2021) PP. 01-14 DOI 10.35631/AIJBAF.39001

Obied and Awad (2017) examined the impact of monetary policy on the performance of the economy of Jordan. The results show that there are long-run and short-run relationships between monetary policy tools and economic growth. It also shows that the discount rate affects the economy negatively. Precious and Palesa (2014) studied the effect of monetary policy instruments on the economy of South Africa. Their findings show the presence of a long-run association between the variables. Moreover, CPI is the most significant instrument that affects growth. Further research of Alavinasab (2016) empirically explores the effects of monetary policies on Iranian economic growth. The study indicates that economic growth is influenced by money supply and exchange rate in the short run.

Dumičić, et al. (2010) examine monetary policy effects on the Croatian economy. The study proves the presence of a relationship among the variables. The variables are significant in explaining domestic income. Thus, money supply and eurozone income affect Croatian income positively. While the exchange rate has a negative impact. Ndzinisa (2008) examined the efficacy of monetary policies on the Swaziland economy. The study further finds that credit extension affects real GDP negatively in the short-run but with positive long-run effects. Ahmad, et al. (2016) recently tested the efficacy of monetary policies on the Pakistan economy. The empirical findings stated that economic growth is affected by money supply and exchange rate positively. While the consumer price index affects economic growth positively, but statistically insignificant and the interest rate negatively affects the economic growth.

Chaitip, et al. (2015) investigated the link between money supply and economic growth of ASEAN countries. The results show the presence of a long-run association between the variables. Moreover, the empirical findings show that GDP is affected positively by (M1). While it is negatively related to demand deposits. The study of Lionel (2014) tests the impacts of monetary policies on the Franc zone economy. The results show that the economic growth of the fourteen countries is positively and significantly affected by the money supply. While, it is negatively and significantly affected by total reserves, inflation rate, and domestic credit. Şen and Kaya (2015) in their recent research studied empirically the effects of monetary and fiscal policies on Turkey's economy. The results indicate that the economic growth of Turkey is significantly affected by both monetary and fiscal policy. However, monetary policies are more efficient than fiscal policies in enhancing the economy. Moreover, the most powerful tool of monetary policy is the interest rate, and the second powerful tool after the interest rate that affects economic growth is the budget deficit as a fiscal policy tool.

Otherwise, some authors have found out that the link between monetary policy and economic growth is relatively weak or it is not existing at all. Lut and Moolio (2015) examine whether monetary policy has any effect on Cambodia's economy. The empirical results show a positive effect of (M2) on GDP, but the strength is relatively weak. While economic growth is not affected by interest rate. Ekobena (2015) tries to detect the effect of monetary policies on the CEMAC region economy. The findings indicate that economic growth is negatively affected by monetary instruments, but the link is relatively weak. Lashkary and Kashani (2011) examined the effects of monetary policies on Iran's economy. The results indicate the absence of a significant association between monetary instruments and economic growth. As a result, the outcome of this study is not consistent with Alavinasab (2016). Cyrus and Elias (2014) Copyright (C) GLOBAL ACADEMIC EXCELLENCE (M) SDN BHD - All rights reserved 
Volume 3 Issue 9 (December 2021) PP. 01-14 DOI 10.35631/AIJBAF.39001

explored the impacts of monetary and fiscal policies on the real output of Kenya. The empirical findings show that economic growth is insignificantly affected by money supply and interest rate. While it is significantly affected by fiscal policies. Hervé (2017) recently examined the effects of monetary policies on the Côte d'Ivoire economy. The results imply that the economy of Côte d'Ivoire does not react significantly to monetary policy shocks.

Few types of research propose that monetary policy does not impact economic growth. While many studies conducted mainly in developed countries that have developed financial markets and independent central banks support this hypothesis where money supply and interest rate affect economic growth positively such as Agbonlahor (2014), Ndzinisa (2008), and Lionel (2014). On the other hand, in developing countries that have less developed financial markets, the relationship between monetary policies and economic growth tends to be weaker such as Lut and Moolio (2015), and Barguellil, et al. (2018). In the case of developing countries, Nguyen et al. (2019) reported that the impact of monetary policy is less clear, possibly due to less developed financial structure.

\section{Literature on Monetary Policy and Economic Growth in Kuwait}

There has been an extensive investigation on how real GDP is affected by money supply, inflation rate, interest rate, and exchange rate. Many empirical types of research have examined the link between monetary policy tools and economic growth in different countries (developed, developing) using different time series (annual, monthly, quarterly) and a different number of observations which have resulted in inconsistent outcomes. Few types of research propose that monetary policy does not impact economic growth. While many studies conducted mainly in developed countries that have developed financial markets and independent central banks support this hypothesis where money supply and interest rate affect economic growth positively such as Agbonlahor (2014), Ndzinisa (2008), and Lionel (2014). On the other hand, in developing countries that have less developed financial markets, the relationship between monetary policies and economic growth tends to be weaker such as Lut and Moolio (2015), and Barguellil, et al. (2018). In the case of developing countries, Nguyen et al. (2019) reported that the impact of monetary policy is less clear, possibly due to less developed financial structure.

Munir Hassan et al. (2017 and Nadeem et al. (2017) analyzed the determinants of long-run economic growth using quarterly data from 1979-2013 by extending the stochastic growth model and develop the K-VARX model. They analyzed to what extent Kuwaiti real output, in the long run, is shaped by oil revenue and foreign output. They found that that real domestic output, in the long run, is influenced by oil revenues and foreign output (a proxy for technological progress), and technological growth in Kuwait is on a par with the rest of the world. Alia Ali Abu-Aisheh (2018) investigates the importance of entrepreneurship to the economic growth of Kuwait. Entrepreneurship is expected to solve the problem of high demands for youth employment in Kuwait in the coming few years. This study used OLS regression to estimate the effect of entrepreneurship on GDP growth using data extracted from Kuwait Central Statistical Bureau, Kuwait Ministry of Finance, World Bank, and United Nations from 2001 to 2014. Rubina (2017) explore the causes of a slowdown of growth, falling revenues from export, and growing budget deficit during 2000-2015 in Gulf Cooperation 
Volume 3 Issue 9 (December 2021) PP. 01-14 DOI 10.35631/AIJBAF.39001

Council (GCC) states, including Kuwait. She found that the volatile oil prices are the cause of growing budget deficits and dwindling current accounts in GCC nations during that period. Hamza et al. (2020) explore the dynamic causal relationship between economic growth and financial development in Kuwait, covering the period between 1991 and 2017. They used the Toda-Yamamoto estimation technique and found that there is no causal direction was found. The second estimation was Fourier Toda-Yamamoto time-domain techniques and they found that the causality flowing from financial development to economic growth. Measurement for financial development was broad money supply as a proportion of GDP (M2), liquid liabilities as a proportion of GDP (M3), bank deposit as a proportion of GDP, and domestic credit provided to the private sector as a proportion of GDP.

\section{Data and Methodology}

To investigate the effects of monetary policies on economic growth. Five variables will be used in our model: real (GDP) as the dependent variable and consumer price index, broad money supply, deposit interest rate, and exchange rate. The annual time series is obtained from the World Bank (WB) for Kuwait over the period (1980-2017). To examine the effect of monetary policies on economic growth we use the model which is presented as follows:

$$
G D P_{t}=\alpha_{0}+\alpha_{1} M S 2_{t}+\alpha_{2} E X_{t}+a_{3} D I R_{t}+a_{4} C P I_{t}+\varepsilon_{t}
$$

Where, $G D P_{t}$ is the natural logarithm of the real GDP (billions of Kuwaiti Dinar), $M S 2_{t}$ is the natural logarithm of broad money supply (billions of Kuwaiti Dinar), $E X_{t}$ is the exchange rate (KD per USD) in percentage, $D I R_{t}$ is the deposit interest rate in percentage, $C P I_{t}$ is the natural logarithm of a consumer price index $(2010=100), \alpha_{0}$ is the intercept, $\alpha_{1}, \alpha_{2}, \alpha_{3}, \alpha_{4}, \alpha_{5}$ are the slope coefficients of the model and $\varepsilon$ is the error term. Moreover, the study uses (VAR) equation to detect whether monetary policy affects economic growth in Kuwait as formulated below:

$$
\begin{aligned}
& R G D P_{t}=\sigma+\sum_{i=1}^{p} \beta_{1}\left(R G D P_{t-i}\right)+\sum_{i=1}^{p} \beta_{2} \Delta\left(M S 2_{t-i}\right)+\sum_{i=1}^{p} \beta_{3} \Delta\left(E X_{t-i}\right) \\
& +\sum_{i=1}^{p} \beta_{4} \Delta\left(D I R_{t-i}\right)+\sum_{i=1}^{p} \beta_{5} \Delta\left(C P I_{t-i}\right)+\varepsilon_{t}
\end{aligned}
$$

Furthermore, the short-run causality between variables can be tested by utilizing (ECM) models which are presented as follow:

$$
\begin{aligned}
& \Delta(R G D P)=\theta_{0}+\sum_{i=1}^{p-1} \theta_{1} \Delta\left(R G D P_{t-i}\right)+\sum_{i=1}^{p-1} \theta_{2} \Delta\left(M S 2_{t-i}\right)+ \\
& \sum_{i=1}^{p-1} \theta_{3} \Delta\left(E X_{t-i}\right)+\sum_{i=1}^{p-1} \theta_{4} \Delta\left(D I R_{t-i}\right)+\sum_{i=1}^{p-1} \theta_{5} \Delta\left(C P I_{t-i}\right)+\lambda_{1} E S T_{(t-i)}+ \\
& u_{t} \\
& \Delta(M S 2)=\theta_{6}+\sum_{i=1}^{p-1} \theta_{7} \Delta\left(R G D P_{t-i}\right)+\sum_{i=1}^{p-1} \theta_{8} \Delta\left(M S 2_{t-i}\right)+ \\
& \sum_{i=1}^{p-1} \theta_{9} \Delta\left(E X_{t-i}\right)+\sum_{i=1}^{p-1} \theta_{10} \Delta\left(D I R_{t-i}\right)+\sum_{i=1}^{p} \theta_{11} \Delta\left(C P I_{t-i}\right)+\lambda_{2} E S T_{(1 t-i)}+ \\
& u_{1 t}
\end{aligned}
$$


Volume 3 Issue 9 (December 2021) PP. 01-14 DOI 10.35631/AIJBAF.39001

$\Delta(E X)=\theta_{12}+\sum_{i=1}^{p-1} \theta_{13} \Delta\left(R G D P_{t-i}\right)+\sum_{i=1}^{p-1} \theta_{14} \Delta\left(M S 2_{t-i}\right)+$

$\sum_{i=1}^{p-1} \theta_{15} \Delta\left(E X_{t-i}\right)+\sum_{i=1}^{p-1} \theta_{16} \Delta\left(D I R_{t-i}\right)+\sum_{i=1}^{p-1} \theta_{17} \Delta\left(C P I_{t-i}\right)+$ $\lambda_{3} \operatorname{EST}_{(2 t-i)}+u_{2 t}$

$\Delta(D I R)=\theta_{18}+\sum_{i=1}^{p-1} \theta_{19} \Delta\left(R G D P_{t-i}\right)+\sum_{i=1}^{p-1} \theta_{20} \Delta\left(M S 2_{t-i}\right)+$ $\sum_{i=1}^{p-1} \theta_{21} \Delta\left(E X_{t-i}\right)+\sum_{i=1}^{p-1} \theta_{22} \Delta\left(D I R_{t-i}\right)+\sum_{i=1}^{p-1} \theta_{23} \Delta\left(C P I_{t-i}\right)+$ $\lambda_{4} \operatorname{EST}_{(3 t-i)}+u_{3 t}$

$\Delta(C P I)=\theta_{24}+\sum_{i=1}^{p-1} \theta_{25} \Delta\left(R G D P_{t-i}\right)+\sum_{i=1}^{p-1} \theta_{26} \Delta\left(M S 2_{t-i}\right)+$ $\sum_{i=1}^{p-1} \theta_{27} \Delta\left(E X_{t-i}\right)+\sum_{i=1}^{p-1} \theta_{28} \Delta\left(D I R_{t-i}\right)+\sum_{i=1}^{p-1} \theta_{29} \Delta\left(C P I_{t-i}\right)+$ $\lambda_{5} \operatorname{EST}_{(4 t-i)}+u_{4 t}$

Where, $\theta_{0}-\theta_{29}$ are the intercept and the short-run coefficients, $\lambda_{t}$ are the coefficients of (ECT) and the speed of adjustment parameter, $u$ are the error terms, $p$ is the ag length and ECT is the error correction term.

The analysis began with (ADF) unit root test on each variable in our model, namely RGDP, MS2, EX, DIR, and CPI, for determining whether the variables are integrated of order zero I (0) or one I (1). After that, to detect the existence of any long-run relationship among the variables in our model, the Johansen cointegration test will be applied. According to the outcomes of the Johansen cointegration test, if the variables are found to be cointegrated, (VECM) will be utilized to examine the long-run relationship between the variables, and the Granger Causality test based on (VECM) will be employed to examine the short-run relationship. Otherwise, (VAR) model will be applied.

\section{Empirical Results and Discussions}

Table 1 summarizes the outcomes of the (ADF) Unit Root test for each variable. The variables are stationary at the first difference which indicates that all the variables which are used in our model are I (1). Therefore, the Johansen cointegration test is used to detect the existence of a cointegration relationship among the variables with the optimal lag length is 3 based on the minimum (AIC).

\section{Table 1 (ADF) Unit Root Test Results}

\section{Level}

Variable Intercep

\section{Real}

GDP

MS2

EX

DIR

CPI
$-0.741$

1.270

$-2.776^{*}$

$-1.676$ $\mathbf{t}$

Intercept and trend

$$
-3.801 * *
$$

$-3.636 * *$

0.010
First difference

\section{Intercept None} and trend

$0.904-6.475^{* * *}$

$-6.353 * * *$ $-6.021 * * *$

3.192

0.637

$-0.847$

$-5.566 * * *$
$-5.894 * * *$
$-7.544 * * *$
$-3.646 * * *$

$-5.847 * * *$

$-5.801 * * *$

$-7.266 * * *$

$-3.604 * *$
$-4.258 * * *$

$-5.933 * * *$

$-7.353 * * *$

Notes: *,** and $* * *$ denote the rejection of the hypothesis at $10 \%, 5 \%$ and $1 \%$ levels of significance, respectively. Notice: the t-statistic is reported. 
Volume 3 Issue 9 (December 2021) PP. 01-14 DOI 10.35631/AIJBAF.39001

Optimal lag length is 3 based on the minimum (AIC) which significance at $5 \%$ significance level. Test for serial correlation was conducted using Autocorrelation LM test. To test whether the error term is normally distributed or not, the Jarque-Bera Normality test was used.

\section{Diagnostic Test Results}

Diagnostic test show that the model does not have serial correlation, the error term is normally distributed and there is no Heteroskedasticity at 5 percent level of significance accordingly. Jarque-Bera Normality test show that the error term is normally distributed at $5 \%$ level of significance. The result also show that there is no Heteroscedasticity in the model at $5 \%$ level of significance.

\section{Johansen Cointegration Test Results}

The Trace and the Maximum Eigenvalue statistics show there is one cointegration equation exists indicated by that the Trace test $=84.52904$ with the P-value $=0.0022$ which is less than 0.05 which means that it is significant at $5 \%$ significance level. The value of Max Eigenvalue $=50.78295$ with the P-value $=0.0002$ which is less than 0.05 , means that it is significant at $5 \%$ significance level. This result therefore indicate the presence of one long-run relationship among the variables. By using real GDP as the dependent variable, the long-run equation is as follows:

$\mathrm{LRGDP}_{\mathrm{t}}=10.03757+0.3687 \mathrm{LMS}_{\mathrm{t}}-2.7093 \mathrm{Ex}_{\mathrm{t}}+0.1119 \mathrm{DIR}_{\mathrm{t}}+1.2844 \mathrm{LCPI}_{\mathrm{t}}$ where LRGDP is long-run Real Gross Domestic Product, LMS2 is a long-run money supply, Ex is the exchange rate, DIR is the deposit interest rate, and LCPI is the long-run consumer price index. Equation (1) indicates that real Gross Domestic Product is related to broad money supply positively, deposit interest rate, and consumer price index while negatively associated with the exchange rate. The coefficients of (M2), (DIR) and (CPI) have a positive sign and they are statistically significant at 5 percent level of significance, which indicates that for every one unit rise in money supply (one billion Kuwaiti Dinar), the real gross domestic product will increase by 0.3687 billion KD. This result supported the study of Agbonlahor (2014); Fasanya et al. (2013); Kareem (2013); Obied and Awad (2017) and Hamza et al. (2020); but not support the study of Srithilat and Sun (2017); Luqman and Migiro (2014). The positive and significant coefficient of (M2) indicates that the money supply has boosted Kuwaiti economic growth. This study reveals the importance of monetary policy in managing economic growth in a small and open economy country like Kuwait. For every one percent rise in deposit interest rate, the real gross domestic product will increase by 0.1119 billion KD. The positive and significant coefficient of (DIR) indicates that the deposit interest rate has an important role in enhancing Kuwaiti economic growth. This result not supported the Keynesian Transmission Mechanism IS-LM Model where an increase in money supply will decrease interest rate which in turn lowers the cost of funds available for lending and that will encourage investors to invest more which results in increasing the output. This study not supported the findings of Fasanya et al. (2013), but support Luqman and Migiro (2014).

Furthermore, for every one unit rise in the consumer price index, the real gross domestic product will increase by 1.2844 billion KD. This result supported the Classical Monetary 


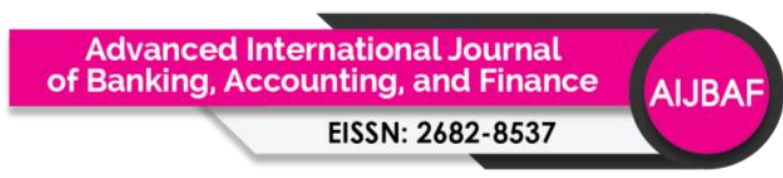

Volume 3 Issue 9 (December 2021) PP. 01-14 DOI 10.35631/AIJBAF.39001

Theory where an increase in money supply will increase the price. The prices will increase faster than output if there is full employment and on the other hand, the output will increase more than the prices if the economy is not in a full-employment situation. This study also supported the Keynesian Transmission Mechanism IS-LM Model where an increase in money supply will increase the price level which in turn will encourage investment and produce more output. This study supported the findings of Fasanya et al. (2013) and Precious and Palesa (2014). Moreover, the coefficient of (EX) has a negative sign and it is statistically insignificant at 5 percent level of significance. The negative and insignificant coefficient of (EX) indicates that real depreciation does not stimulate exports of Kuwait and affects economic growth negatively. These findings support the study of Barguellil, et al. (2018), which indicates that the exchange rate affects economic growth negatively in developing countries. Whereas it is not significant in countries with fixed regimes. Thus, the fluctuation of the exchange rate does not affect economic growth. As a result, in the long run, the most significant component of monetary policy tools that boosted the Kuwaiti economic growth is the broad money supply.

\section{Granger Causality Tests Results}

The Granger Causality test was used to test the causal relationship between variables. Estimation was done by using real GDP as a dependent variable, followed by money supply, exchange rate, deposit interest rate, and consumer price index as the dependent variable. The Chi-square (P-value) outcomes indicate the short-run relationship while the sign of EST(-1) coefficient and its P-value show the long-run relationship. The results of regressions in qoloumn 2 show that there is a long-run causality running from the independent variables to the dependent variable (real GDP).

Table 2 Result of VECM

\begin{tabular}{|c|c|c|c|c|c|c|c|c|c|c|}
\hline Dependent & \multicolumn{2}{|c|}{ GDP } & \multicolumn{2}{|c|}{ M2 } & \multicolumn{2}{|c|}{ EX } & \multicolumn{2}{|c|}{ DIR } & \multicolumn{2}{|c|}{ CPI } \\
\hline Variables & Coeff. & Prob. & Coeff. & Prob. & Coeff. & Prob. & Coeff. & Prob. & Coeff. & Prob. \\
\hline EST1(-1) & -0.60 & 0.00 & 0.06 & 0.29 & -0.01 & 0.21 & 2.20 & 0.09 & 0.00 & 0.71 \\
\hline $\operatorname{GDP}(-1)$ & -0.18 & 0.34 & 0.08 & 0.14 & 0.01 & 0.00 & -1.74 & 0.17 & 0.02 & 0.26 \\
\hline $\operatorname{GDP}(-2)$ & -0.43 & 0.06 & -0.03 & 0.62 & -0.00 & 0.77 & -0.55 & 0.70 & 0.01 & 0.62 \\
\hline M2(-1) & 1.34 & 0.10 & 0.39 & 0.09 & -0.01 & 0.78 & 0.38 & 0.93 & 0.07 & 0.48 \\
\hline M2(-2) & 0.79 & 0.19 & -0.00 & 0.98 & -0.01 & 0.75 & -6.26 & 0.11 & 0.04 & 0.55 \\
\hline EX(-1) & -3.94 & 0.33 & -1.72 & 0.15 & -0.01 & 0.95 & 15.60 & 0.55 & 0.85 & 0.12 \\
\hline EX(-2) & -4.31 & 0.23 & -0.43 & 0.67 & -0.40 & 0.05 & -1.88 & 0.93 & 0.10 & 0.82 \\
\hline $\operatorname{DIR}(-1)$ & -0.05 & 0.09 & 0.00 & 0.99 & -0.00 & 0.38 & 0.19 & 0.38 & 0.01 & 0.03 \\
\hline DIR(-2) & -0.03 & 0.27 & 0.00 & 0.44 & -0.00 & 0.55 & -0.08 & 0.62 & -0.00 & 0.61 \\
\hline CPI(-1) & -4.97 & 0.01 & 0.52 & 0.34 & 0.09 & 0.55 & 7.41 & 0.53 & 0.73 & 0.00 \\
\hline CPI(-2) & -2.78 & 0.22 & -0.16 & 0.80 & -0.06 & 0.61 & 5.92 & 0.68 & -0.29 & 0.33 \\
\hline C & 0.14 & 0.01 & 0.02 & 0.17 & -0.00 & 0.85 & -0.11 & 0.75 & 0.00 & 0.31 \\
\hline R-squared & 0.55 & & 0.60 & & 0.30 & & 0.31 & & 0.64 & \\
\hline $\begin{array}{l}\text { Adjusted R- } \\
\text { squared }\end{array}$ & 0.34 & & 0.41 & & -0.02 & & -0.00 & & 0.47 & \\
\hline F-statistic & 2.66 & & 3.18 & & 0.91 & & 0.97 & & 3.84 & \\
\hline
\end{tabular}


Volume 3 Issue 9 (December 2021) PP. 01-14

Prob

statistic)

Akaike criterion

Schwarz

criterion

Durbin-

Watson stat

$$
\text { (F- } \quad 0.02
$$

info -0.92

$-0.39$

1.88
0.00

$-3.37$

$-2.83$

2.06
0.53

$-6.67$

$-6.14$

2.04 DOI 10.35631/AIJBAF.39001

0.49

2.80

3.33

1.91
0.00

2.03

Column 4 shows that the coefficient of EST(-1) is positive and insignificant (P-value $=0.2918$ $>0.05)$ which indicates there is no long-run causality at $5 \%$ significance level running from the independent variables to the broad money supply. Column 6 shows the coefficient of EST(1 ) is negative and insignificant with $\mathrm{P}$-value $=0.2169>0.05$ ) which indicates there is no longrun causality at $5 \%$ level of significance running from the independent variables to exchange rate. The coefficient of EST $(-1)$ is 2.201862 but insignificant $(\mathrm{P}$-value $=0.0995)$ which is greater than 0.05 . This indicates that there is no long-run causality at $5 \%$ significance level running from the independent variables to the broad interest rate. The coefficient of EST(-1) is positive and significant $(\mathrm{P}$-value $=0.7133>0.05)$ which indicates there is no long-run causality at $5 \%$ level of significance running from the independent variables to the consumer price index.

Short-run relationship and Wald Test in Table 3 shows that there is the long-run impact from the independent variables to real GDP and two unidirectional short-run relationships from broad money supply and consumer price index to real GDP. When the broad money supply and exchange rate and deposit interest rate were used as the dependent variable, the results do not show any long-run or short-run impact between the variables. To conclude, when monetary policy variables become the dependent variable one by one, the result indicates that no causal relationship whether in the long run or short run. However, when the real GDP is used as the dependent variable, the results show one bidirectional long-run relationship running from monetary policy instruments to real gross domestic product. Thus, there are two unidirectional short-run relationships, the first one runs from broad money supply to real GDP and the second one runs from consumer price index to real GDP.

Table 3 Results From Granger Causality Tests And Wald Tests

$\begin{array}{llllllll} & \sum \Delta & \sum \Delta \text { MS2 } & \sum \Delta & \sum \Delta & \sum \Delta \text { CPI } & \text { Jointly } & \text { EST (-1) } \\ & \text { RGDP } & & \text { EX } & \text { DIR } & & & \\ \Delta & - & 0.0288^{* *} & 0.2967 & 0.1335 & 0.0022 * * * & 0.0094 * * * & - \\ \text { RGDP } & & & & & & & 3.0663 * * * \\ \Delta \text { MS2 } & 0.2723 & - & 0.3109 & 0.7386 & 0.6258 & 0.3971 & 1.0790 \\ \Delta \text { EX } & 0.5930 & 0.9352 & - & 0.5897 & 0.6566 & 0.9789 & -1.2696 \\ \Delta \text { DIR } & 0.3562 & 0.2366 & 0.8289 & - & 0.6709 & 0.6768 & 1.7167 \\ \Delta \text { CPI } & 0.4625 & 0.5168 & 0.2693 & 0.0560 * & - & 0.0073 * * * & 0.3720\end{array}$

Note: $* * *, * *$ and $*$ denote significance at the $1 \%, 5 \%$ and $10 \%$ levels, respectively. Notice: EST (-1) represents the error correction term lagged one period. Chi-square (P-value) for the lagged variables are reported here. For the EST (-1) the t-statistics are reported instead. 
Volume 3 Issue 9 (December 2021) PP. 01-14

DOI 10.35631/AIJBAF.39001

\section{Impulse Response Functions (IRFs) Results}

The Impulse Response Functions are utilized to observe the reaction of the real GDP of Kuwait to one-unit standard deviation shock on monetary instruments. According to the left-upper graph in Figure 1, after one-standard-deviation shock on broad money supply, real GDP indicates positive-insignificant reaction and remains positive throughout the period, but it becomes closer to the axis after the $5^{\text {th }}$ period. While, after one-standard-deviation shock on the exchange rate, real GDP indicates positive-insignificant reaction and remains positive throughout the period, but real GDP responds significantly to the shock on exchange rate after the fourth period until the sixth period.

Moreover, real GDP fluctuates throughout the period with insignificant reaction to the shock on the deposit interest rate and Consumer Price Index. To conclude, real GDP reacts insignificantly to broad money supply, deposit interest rate, and consumer price index. While it has a significant reaction to the shock on exchange rate after the fourth period until the sixth period.

Response to Cholesky One S.D. Innovations \pm 2 S.E.

Response of LRGDP to LMS2

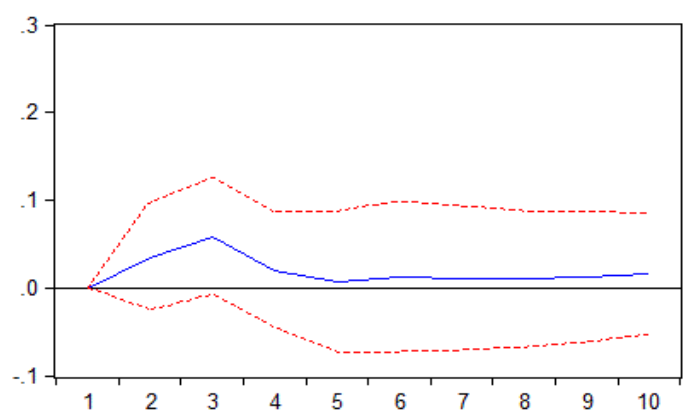

Response of LRGDP to DIR

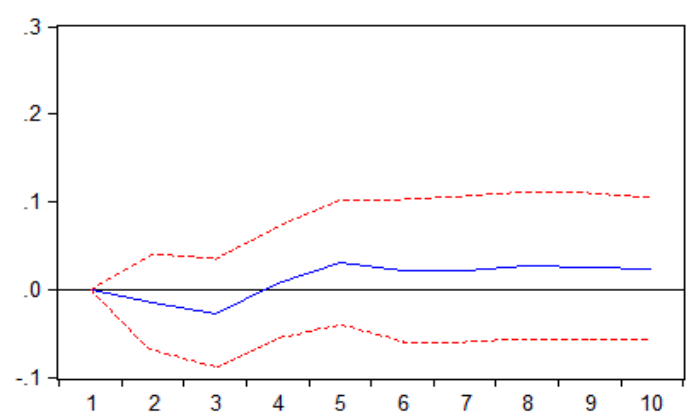

Response of LRGDP to EX

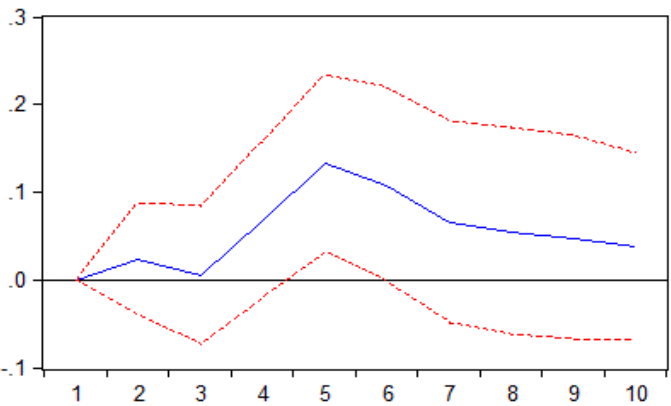

Response of LRGDP to LCPI

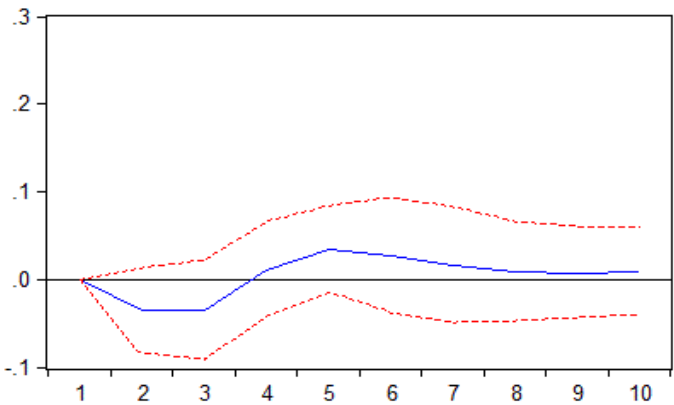

Figure 1: The Impulse Response Functions of Real GDP to The Variables

\section{Conclusion}

The main purpose of the study is to explore the effect of monetary policy instruments on Kuwaiti economic growth. The Granger causality test result indicates the presence of two 
Volume 3 Issue 9 (December 2021) PP. 01-14 DOI 10.35631/AIJBAF.39001

bidirectional short-run causal relationships running from broad money supply and consumer price index to real GDP. These results mean that the Keynesian transmission mechanism and the monetarist hypothesizes are valid in Kuwait in the long run. Real GDP has a positive reaction after one-standard-deviation shock on broad money supply and exchange rate. While the reaction of real GDP to the shock on deposit interest rate and consumer price index fluctuates throughout the period. Thus, real GDP reacts insignificantly to broad money supply, deposit interest rate, and consumer price index. While it has a significant reaction to the shock on exchange rate after the fourth period until the sixth period. Broad money supply (M2) is the strongest monetary tool in influencing Kuwaiti economic growth. This research proposes that the (CBK) must rethink applying monetary instruments to improve Kuwaiti economic growth by utilizing the best instruments as broad money supply and interest rates as opposed to exchange rates to ensure Kuwait's economic stability. It, accordingly, suggests that the Kuwait policymakers must concentrate on improving the economy by guaranteeing that increasing the supply of money is corresponding to the increasing in real GDP. Furthermore, the state of Kuwait is mindful that the dependence on oil revenue is an exhaustible resource for the sustainability of Kuwait's economy. Therefore, the study suggests that policymakers manage interest rates and financial environment that entices investors through proper adjustment of monetary policy instruments to achieve sustainable economic growth and development.

\section{Acknowledgment}

This paper was modified by the author from the SME 599 project paper submitted by Khaldoun $\mathrm{Abu}$ Saed as a partial requirement for fulfillment of the Master Degree of Economic Management, School of Social Sciences, Universiti Sains Malaysia.

\section{References}

Agbonlahor, O. (2014). The Impact of Monetary Policy on The Economy of The United Kingdom: A Vector Error Correction Model (VECM). European Scientific Journal, 10(16), 19-42.

Alia Ali Abu-Aisheh. (2018). Entreprenuership and economic growth: Case of Kuwait. SciencesPo Kuwait Program. https://www.sciencespo.fr/kuwait-program/wpcontent/uploads/2018/11/Alia-Ali-Abu-Aisheh-Entrepreneurship-and-EconomicGrowth.pdf

Barguellil, A., Ben-Salha, O., \& Zmami, M. (2018). Exchange Rate Volatility and Economic Growth. Journal of Economic Integration, 33(2), 1302-1336.

Enock, N.T., \& Nicholas, M.O. (2018). Monetary policy and economic growth: A review of International Literature. Journal of Central Banking Theory and Practice, 7(2), 123137.

Fasanya, I. O., Onakoya, A. B., \& Agboluaje, M. A. (2013). Does Monetary Policy Influence Economic Growth in Nigeria? Asian Economic and Financial Review, 3(5), 635-646.

Financial Stability Office. (2017). Financial Stability Report. Kuwait: Central Bank of Kuwait. Granger, C. W. (1969). Investigating Causal Relations by Econometric Models and Crossspectral Methods. Econometrica, 37(3), 424-438.

Hamza, A., Huseyin, O., \& Andisheh, S. (2020). Does financial development promote growth in Kuwait? Time-and frequency-domain causality testing. The Journal of International 
Volume 3 Issue 9 (December 2021) PP. 01-14 DOI 10.35631/AIJBAF.39001

Trade \& Economic Development, An International and Comparative Review, 29(8), 952-972.

Lionel, D. T. (2014). Assessing The Effect of Monetary Policy on Economic Growth in Franc zone. Rennes: Department of Banking and Finance.

Munir Hassan, Anwar Al Shriaan, \& Abdullah k Al-Mutairi. (2017). An Analysis of Kuwait Economy 1995-2015. Asian Social Sciences, 13(12), 24-34.

Nadeem A. Burneya, Kamiar Mohaddesb , Ahmad Alawadhiay, and Marwa Al-Musallam. (2017). The Dynamics and Determinants of Kuwaitís Long-Run Economic Growth. http://www.econ.cam.ac.uk/peoplefiles/faculty/km418/Macroeconometric_Model_for_Kuwait.pdf.

Ndzinisa, P. (2008). The Efficacy of Monetary Policy on Economic Growth in Swaziland. Swaziland: The Central Bank of Swaziland, Research Depatment.

Nguyen, T,M,L., Papyrakis, E. , \& Bergeijk, P.A.G.V. (2019). Assessing the price and output effects of monetary policy in Vietnam: Evidence from a VAR analysis.

Obied, R., \& Awad, B. (2017). Effectiveness of Monetary Policy Instruments on Economic Growth in Jordan Using Vector Error Correction Model. International Journal of Economics and Finance, 9(11), 194-206.

Rubina, V. (2017) The Impact of Oil Prices on GCC Economies. International Journal of Business and Social Sciences, 8(2), 7-14.

Srithilat, K., \& Sun, G. (2017). The Impact of Monetary Policy on Economic Development: Evidence from Lao PDR. Global Journal of Human-social Science: Economics, 17(2), 9-15. 